INTERNATIONAL

INSTITUTE FOR

LABOUR STUDIES

Discussion paper

DP/144/2002

Labour and

Society

Programme The resurgence of the Italian
Confederal Unions: Will it last?

Lucio Baccaro, Mimmo Carrieri, Cesare Damiano 
The International Institute for Labour Studies was established in 1960 as an autonomous facility of the International Labour Organization (ILO). Its mandate is to promote policy research and public discussion on emerging issues of concern to the ILO and its constituents - government, business and labour.

The Discussion Paper Series presents the preliminary results of research undertaken by the IILS. The documents are intended for limited dissemination with a view to eliciting reactions and comments before they are published in their final form in the Research Series or as special publications. 


\section{The resurgence of the Italian Confederal Unions: Will it last?}

Lucio Baccaro, Mimmo Carrieri, Cesare Damiano

International Institute for Labour Studies Geneva 
Copyright (C International Labour Organization (International Institute for Labour Studies) 2002. Short excerpts from this publication may be reproduced without authorization, on condition that the source is indicated. For rights of reproduction or translation, application should be made to the Editor, International Institute for Labour Studies, P.O. Box 6, CH-1211 Geneva 22 (Switzerland).

ISBN 92-9014-665-6

First published 2002

The responsibility for opinions expressed in this paper rests solely with its author(s), and its publication does not constitute an endorsement by the International Institute for Labour Studies of the opinions expressed.

Requests for this publication should be sent to: IILS Publications, International Institute for Labour Studies, P.O. Box 6, CH-1211 Geneva 22 (Switzerland). 


\section{TABLE OF CONTENTS}

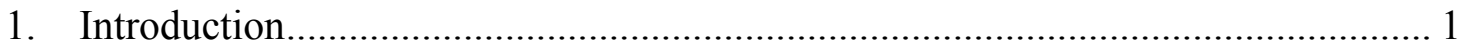

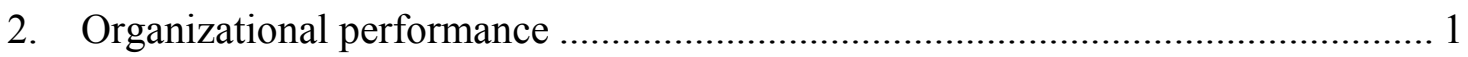

3. Relationships with political parties and governments ....................................... 4

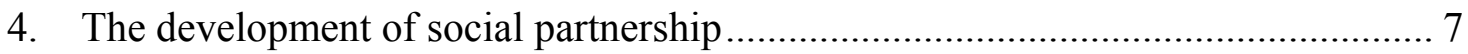

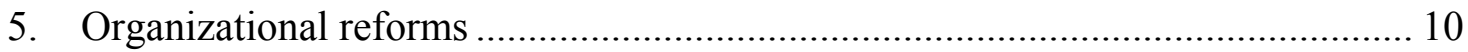

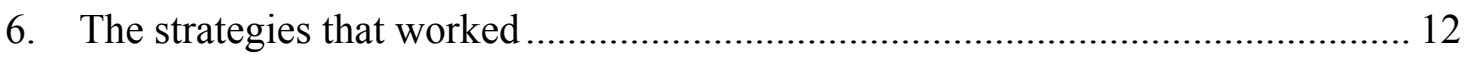

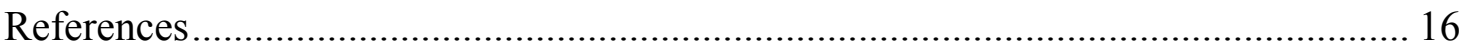

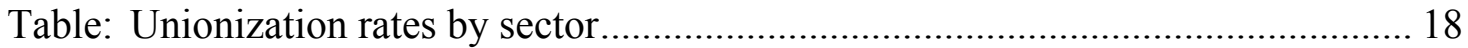




\section{Abstract}

This paper seeks to explain the political renaissance of the Italian confederal unions in the 1990s by linking it to a combination of essentially three factors: the opening up of new opportunities in the political sphere, unity of action among the three major confederations, and a series of organizational reforms that increased the unions' capacity for encompassing, inclusive representation. If the main determinants of the Italian unions' renaissance are to be found in the political sphere, it is from this sphere, according to the authors, that the major challenges for the future are likely to emerge. In particular, the resurfacing of competition among the three major confederations could make it increasingly difficult for the Italian unions to speak with a single voice not just in the political, but also in the economic sphere. 


\section{Introduction}

Overall, the past ten years were a good decade for the Italian unions, even though, just like most other unions in most advanced countries, they lost some members. In Italy, however, this loss was smaller than elsewhere and appears to have been slowing down in the 1990s compared with the 1980s.

It is, however, in the political, much more than in the organizational sphere, that the clearest signs of renaissance are to be found. Following the demise of the governments of National Solidarity in 1979 and the burning defeat of the metalworkers' union in the Fiat strike of 1980, the three confederal unions, CGIL, CISL, and UIL, experienced an erosion of their political, economic, and organizational power in the 1980s (Locke: 1995, ch. 3). The failure of tripartite bargaining in 1984, combined with insistent demands particularly from the metalworking employer federation to shift from collective bargaining to individualized relations between employers and employees (Mortillaro, 1984; 1986), seemed to usher in an era of political and economic marginalization for the Italian labor movement. Some scholars wondered aloud whether the Italian unions still had a future as national organizations (Locke, 1992). Quite surprisingly, however, the confederal unions regained strategic initiative in the 1990s and were able to not only participate, but also significantly influence virtually all of Italy's political economic decisions, from income policies to labor market flexibilization to pension reform (Locke and Baccaro, 1999).

This paper argues that the political renaissance of the Italian confederal unions is linked to a combination of essentially three factors, the opening up of new opportunities in the political sphere, unity of action among the three major confederations, and a series of organizational reforms that increased the unions' capacity for encompassing, inclusive representation. In the early 1990s, almost all of Italy's political parties collapsed in the space of a few months. Simultaneously, the Italian policy-making authorities had to face one of the most serious financial crises in the country's post-war history. Reinvigorated by internally democratic reforms that both strengthened their links with the rank-and-file and increased their legitimacy vis-à-vis other, competitive worker associations, the three confederations, CGIL, CISL, and UIL, were able to play a key role in this phase of political and economic emergency (see also Salvati, 2000). This led to the institutionalization of a system of corporatist policy-making in Italy - a system in which governments and the unions, less so the organized employers, were the major actors.

If the main determinants of the Italian unions' renaissance are to be found in the political sphere, it is from this sphere, in our opinion, that the major challenges for the future are likely to emerge. As the political party system re-establishes itself after the crisis of the early $1990 \mathrm{~s}$, it comes to regard the unions' heavy involvement in national policy-making increasingly as an intrusion. The recent accession to power of a center-right government, backed by a more stable electoral majority than the preceding center-left governments, could very well spell the end of Italian corporatism. Also, organizational reforms aimed at ensuring closer relations between the unions and the rankand-file workers seem to have lost momentum and no longer figure prominently on the policy agenda. Finally, and perhaps most importantly, the Italian unions' political role is threatened from within by the re-emergence of competition among the major confederations. If these divisions persist, it will become increasingly difficult for the Italian unions to speak with a single voice not just in the political, but also in the economic sphere.

The remainder of the paper is organized as follows. We begin with an overview of the unions' organizational performance. We then consider the relationship between the unions and the political/institutional arena. In section three, we discuss the development of social partnership. Section four reviews a series of organizational reforms. We conclude by discussing successful union strategies and by speculating on possible future developments.

\section{Organizational performance}


The performance of the Italian confederal unions, CGIL, CISL, and UIL, is far from impressive when considered from the point of view of membership trends and density rates alone. The number of dues-paying members grew considerably in the 1980s and 1990s. However, all of this increase was among retired members. The number of active workers declined by 2,014,559 units $(28.2$ percent) between 1980 and 1998. As a result, the unionization rate fell from 49 percent in 1980 (the peak year) to slightly above 35 percent in 1998. In 1998, retired workers accounted for 49.4 percent of total membership, up from 18.1 percent in 1980 (Codara, 2000).

The situation appears in slightly more positive light if one looks at different sub-periods and sectors as well as other countries. Data collected by the ILO show that compared with other nations included in this study, the Italian unions did relatively well (ILO, 1998). With the exception of Spain, which increased its membership between 1985 and 1994 (starting, however, from a very low baseline), all other countries in this study experienced greater membership losses and/or greater declines in unionization than Italy. In Italy, most of the decline in active membership occurred in the 1980s (1,265,164 units), not in the 1990. Preliminary data on 1999 and 2000 seem to suggest that the hemorrhage of members has now stopped and that the confederal unions are once again attracting workers, not just pensioners. Between 1998 and 2000, the number of active workers affiliated to the CGIL (CISL) [UIL] increased from 2,303,653 (1,833,305) $[1,174,243$ ] to $2,341,743$ $(1,934,854)[1,786,879]$.

Data on unionization rates by sector reveal a marked decline in agriculture between 1981 and 1997 (-13.36 percent). ${ }^{1}$ The industrial sector declined less (-8.42 percent). Interestingly enough, most of the decline in industry occurred between 1981 and 1990 (-7.12 percent). Between 1990 and 1997, the loss was of 1.3 percentage points, i.e., much lower (see Table 1). These data show that in spite of the recent losses, the Italian confederal unions are remarkably strong in agriculture and still considerably strong in the industrial and public sectors, where the unionization rates are 40 and 45 percent respectively. The strength of unions in these sectors is magnified by the de facto presence (even though not de jure) of institutional mechanisms for the extension of collective bargaining agreements to non-unionized workers and companies. With a unionization rate of 20 percent, the three main confederal unions are, instead, much weaker in the private tertiary sectors, i.e., those in which new employment is being created. Furthermore, their strength in these sectors appears to have declined over time.

Similar to other Mediterranean countries like France and Spain, in Italy as well the strength of unions is increasingly being evaluated not just in terms of their membership, but also on the basis of their performance in workplace elections. In this particular domain, the confederations' record is quite remarkable. All workers, both union members and non-, elect a form of Works Councils known as Rappresentanze Sindacali Unitarie (RSU) (see below). These elections are held on a voluntary basis in the private sector, as no law regulating these organizational structures has been passed yet. In 1996, elections had been held in 9,600 private workplaces employing 1.7 million workers. The workers' participation rate was remarkably high (72 percent) - higher than voter turnout in recent political elections and referenda. The three confederal unions obtained 95.5 percent of the votes. With almost 50 percent of the vote, CGIL emerged as the most representative organization, followed by CISL (20 percent), and UIL (16 percent) (see also Carcano, 2000). The electoral weight of non-confederal union organizations appeared to be negligible in the private sector. In some sectors, like railways and air transportation, and particularly within particular

\footnotetext{
1 The fact that the unionization rate in agriculture was 100.06 percent in 1981 (see Table 1), i.e. higher than the number of workers themselves, suggests the possibility of overreporting in this sector.
} 
occupational communities, like locomotive engineers and pilots, the organizational weight of the non-confederal unions was, however, much more substantial. ${ }^{2}$

Workplace elections are mandatory in the public sector. In 1997, the so-called Legge Bassanini regulated the periodic election of worker representatives as well as the official counting of membership data. The purpose of these measures was the assessment of "representativeness" (rappresentatività). The unions that passed a threshold of five percent (calculated as average between electoral votes and quota of membership cards) were designated as "representative" and were allowed to participate in collective bargaining in the various public sector compartments (e.g. schools, ministries, municipalities, etc.) as well as sign collective bargaining agreements that were binding for all workers.

The public sector elections were held at the end of 1998 (at the end of 2000 in the school compartment). The participation rate was 75 percent ( 77 percent in the schools), i.e., even higher than in the private sector. This is a clear sign that workers care about union democracy. The confederal unions obtained a cumulative 70 percent of the vote. Non-confederal unions obtained 30 percent, a respectable proportion. The unionization rate was 49.9 percent $(39.5$ percent in the schools). The three confederal unions organized 37.5 percent of all public sector workers $(25.5$ percent in the schools). The remaining portion was organized by alternative organizations. ${ }^{3}$ While the CISL had more members than the CGIL in the public sector, the latter attracted more votes. The number of votes obtained by the CISL was, in fact, lower than the number of membership cards which implies that not all CISL members voted for CISL candidates. The other two confederations received more votes than they had members.

The official data on the public sector are interesting for other reasons as well. Most of the literature on the Italian unions focuses on the three major confederations. Yet, these are not the only unions in the country. A myriad of alternative organizations emerged in the 1970s and 1980s. As argued later in the paper, many of these organizations vociferously contested the confederal unions' claim to speak in the name of the Italian workers as a whole. Prior to the public sector elections, the organizational strength of these "other" organizations had to be assessed on the basis of self-reported data. According to these, more than five million workers were affiliated to CISAL, CONFSAL, and UGL (CISNAL until 1995), three of the most important non-traditional confederations. Of these, 3.6 million were active workers (CESOS, various years). ${ }^{4}$

The membership data officially gathered in the public sector provided a check on the reliability of these self-reported data. In 1996, the CONFSAL alone declared 417,175 members in the public sector. This is 26 percent more than the certified number of workers affiliated to all non-confederal unions in 1998. If one adds the self-reported figure of UGL in 1997 (137,461), the total becomes 67 percent greater than the officially certified count. ${ }^{5}$ It seems quite clear that at least some of the non-traditional confederations inflate both their numbers and their claims to representativeness (at least in the public sector). Being able to show this through hard data was no negligible accomplishment for the CGIL, CISL, and UIL.

To conclude, the assessment of the Italian confederal unions' organizational health needs to consider various elements. These unions lost members among active workers in the 1980s and 1990s (although less so in the 1990s than in 1980s). Also, unionization rates fell. At the same time, however, the unions' electoral performance was quite remarkable. With 95 percent of the

\footnotetext{
2 We thank Carla Ricci, of the Organizational Department of the CGIL, for making these data available to us.

3 The source of these data is ARAN, i.e. the public sector collective bargaining agency.

4 If we were to add these figures to the number of active workers organized by CGIL, CISL, and UIL (about 5.3 million in 1996), we would have a total of 8.9 million union members, corresponding to a unionization rate of more than 60 percent.

5 This total does not even include the membership of CISAL, which is believed to be the most representative among the non-traditional organizations.
} 
votes in the private sector and 70 percent in the public sector, the three confederal unions were able to validate their claim to general representation of the Italian workers. This allowed them to weather the challenge of non-traditional associations. These electoral mechanisms proved to be quite important as they increased the confederal unions' legitimacy in the face of the public at large at a time in which important changes in the "political opportunity structure" (Tarrow, 1994), particularly the collapse of all major political parties, created major openings for them in the political and institutional arena. It is to these developments that the paper now turns.

\section{Relationships with political parties and governments}

The Italian unions are well known for their close ties to political parties (Weitz, 1975; Golden, 1988). Political parties were, in fact, largely responsible for the refoundation of the Italian labor movement in the early post-war period. Originally, the movement had a unitary organizational structure. With the onset of the cold war, however, the catholic and socialdemocratic components seceded from the unitary CGIL and created their own autonomous organizations, the CISL and the UIL, respectively.

The CISL had close ties with the Christian Democratic Party. This organization was not a purely confessional union, however. It sought to bring to Italy a model of pragmatic, "business" unionism whose focus was not on ideological principles, but rather on the concrete defense of the workers' interests through collective bargaining, particularly at the workplace level (Baglioni, 1980; Locke and Baccaro, forthcoming). The UIL was initially linked with the Socialdemocratic and Republican Parties. As the strategies of the Communist and Social Parties began to diverge in the early 1960s, the UIL became increasingly connected with the Socialist Party (PSI). The CGIL had two major internal components, the Communist faction, which held the majority of seats in all directive organs, and the Socialist faction. ${ }^{6}$ During the 1980s, the Socialist Party became an integral part of government coalitions with the Christian Democrats and other smaller centrist parties. In these same years, the Communist Party acted as the major opposition party. Even in this period, however, the CGIL struggled to maintain its unitary structure by mediating between communist and socialist leaders within its ranks. This meant that the strategic orientation of the CGIL was generally more moderate than that of the PCI.

Political divisions were responsible (even though not solely responsible) for the collapse of the first phase of Italian corporatism. Similar to virtually all of the advanced countries, in the late1970s/early 1980s inflation became Italy's major socioeconomic problem (Armstrong, Glyn, and Harrison, 1991). This problem was made more serious in Italy by the country's heavy dependence on oil, by the massive wage push of the Hot Autumn years (1969-73), and by the less than perfectly competitive structure of markets, particularly in the distribution sector, which fuelled price increases (Locke, 1995: ch. 3; Salvati, 1984).

Following a number of minor peak-level deals in the late 1970s, the unions signed a tripartite agreement with Confidustria and government in 1983. This agreement reduced wage indexation, introduced wage ceilings for sectoral bargaining, and banned plant-level bargaining for 18 months. The agreement was preceded (and in all likelihood legitimated as well) by a preliminary consultation of the rank-and-file workers. Approximately 69 percent of 4.1 million voters approved the deal. The PCI was far from happy with the content of the tripartite pact. Yet, it did not openly contest it

\footnotetext{
${ }^{6}$ After the events of 1968-69 and the emergence of leftist extra-parliamentary groups, a small "third component" faction was formed in the CGIL.
} 
When the 1983 agreement came up for renewal one year later, the union confederations split. While the CISL, the UIL, and the Socialists within the CGIL approved the government-proposed predetermination of wage increases, the Communist faction within the CGIL contested it. Not all sources of dissent were of political nature. Some were purely union-specific. For example, the CGIL insisted that the final agreement could be signed only if the workers preliminarily ratified it through a referendum. The CISL, instead, was against such referendum. In the end, the referendum was not organized, the CGIL refused to sign the deal, and the government included the content of the proposed agreement in an executive order (to give it general legal validity).

In 1985, the PCI organized a popular referendum to repeal this executive order. This move aimed at healing the offence to procedural democracy which, in the PCI's opinion, the government had perpetrated by forcing through an agreement that had been rejected by the largest union in the country, the CGIL, and which had not been explicitly approved by the workers. The results of the referendum were favorable to government and its allies within the union movement.

The events of 1984-85 brought the Hot Autumn practice of unity of action among the three confederations to an end, not only at the national but also at the local level. In some factories, the unitary Consigli di Fabbrica (work councils) were replaced by organization-specific Rappresentanze Sindicale Aziendali.As a result of these developments, large-scale tripartite agreements were no longer been attempted for the rest of the 1980s.

The relationship between the major union confederations and political parties changed dramatically between the late 1980s and the early 1990s. Following the collapse of the Berlin wall and of the communist regimes of Eastern Europe, the PCI completed its ideological transformation. In 1989, this party refounded itself, changed its denomination into "Democratic Party of the Left" (PDS), officially pledged allegiance to parliamentary and reformist methods of political action, and decided to apply for membership in the Socialist International, i.e., the international association of socialdemocratic parties. The foundation of the PDS provoked an internal scission, as a group of PCI leaders seceded and established a new party of "Refounded Communists"(RC).

In early 1992, a wave of corruption scandals, known as Tangentopoli (bribesville), shook the country. Initially, it appeared that the scandals would only affect some regional and local party leaders. However, the investigation soon escalated and reached the very peak levels of all political parties including the Christian Democrats, the Socialists, and (to a lesser extent) the former Communists. Some of these leaders were forced to resign. Both the DC, Italy's largest political party, and the PSI went through a tremendous legitimation crisis and disappeared. In the midst of political confusion, Silvio Berlusconi, a media tycoon, established his own political party. This was presented as at the same time a "new" party, i.e., uncompromised with the corruption and inefficiency of the past, and as the continuation of the Christian Democratic and Socialist parties. The denomination of the new party, Forza Italia (Come on Italy) resonated with Italy's diffuse sentiments of soccer-related patriotism. Forza Italia built an electoral coalition with the formerfascist Alleanza Nationale and with the rising Northern League and won the elections of 1994.

The political crisis of the early 1990s was accompanied by an equally serious economic crisis. Inflation slowly declined throughout the 1980s but continued to be higher in Italy than in the major trading partners. These developments had dire consequences for the viability of the exposed sectors and in general, for Italy's macroeconomic stability. In fact, for Italian producers to maintain their cost competitiveness at a time when the Lira was tied to the European Monetary System (EMS), i.e., a system of semi-fixed exchange rates, wage increases in the sectors exposed to international competition needed to remain within the limits of international inflation rates plus domestic productivity rates. However, the productivity of the industrial sectors declined in the late 1980s, while the country's inflation rates were consistently higher than most international competitors in the 1980s. The Lira became increasingly overvalued, in real terms, vis-à-vis all major currencies (Modigliani et al., 1996: 38). Besides creating balance-of-payment problems, this situation generated expectations about a possible devaluation of the currency. In fact, it became increasingly 
clear that unless all European central banks jointly defended the nominal parity of the Lira, this would be forced to devalue (see Vaciago, 1993).

These expectations fulfilled themselves in September 1992, when growing doubts about the future viability of the EMS generated a true and proper run on the Lira and other weak currencies like the British Pound. The Lira was forced out of the EMS and lost up to 50 percent of its value vis-à-vis the D-Mark in only a few months.

Paradoxically, the concomitance of both political and economic crisis provided the Italian confederal unions with a major opportunity to impose themselves on the national political sphere as the most important partners of "emergency" governments.

The governments of 1992, 1993, and 1995 were, from the point of view of parliamentary support, extremely weak governments, devoid of clear majorities and (as in the case of the 1993 and 1995 executives) often composed of independent "technicians" formally unaffiliated to any political party. At the same time, the range of tasks these governments had to perform was daunting. First, it was important to avoid that the nominal devaluation of the Lira sparked a new inflationary spiral. ${ }^{7}$ In other words, workers needed to accept wage moderation, and for this, the unions' collaboration was indispensable. Second, since the state of the Italian public finances was disastrous (public deficit was around 10 percent of GDP between 1992 and 1993 and public debt peaked at 125 percent of GDP in 1994), deflationary tendencies could not be counterbalanced by countercyclical (Keynesian) policies. Instead, Italy's economic authorities needed to engage in fiscal consolidation - a set of policies that is generally quite unpopular as it involves cuts in public expenditures and/or raises in taxes (in Italy it involved both).

In the early 1990s, the three confederal unions were uniquely placed to provide the support and collaboration governments needed. First, unlike other major socio-political actors in Italy (e.g., the employers and the politicians), they came out of the Tangentopoli wave of scandals virtually unscathed. Second, through the organizational changes described later in the paper, they had been able to overcome the competition of alternative worker organizations and relaunch their legitimacy as representatives of the Italian working-class as a whole. Third, due to the deep transformations occurred in the structure of political parties, the unions' political sponsors either had disappeared or were (for the first time in Italy's post-war history) sitting together in the same center-left coalition. Between 1992 and 1998, a series of peak-level bargaining agreements were negotiated by the three confederal unions and the Italian governments, with or without (as in the case of the 1995 pension reform agreement) the Confindustria (see below).

Unlike the first, the second phase of Italian corporatism in the 1990s was characterized by close unity of action among the three major confederations. This phase may be turning to an end now. In fact, the last few months have seen the renaissance of competition particularly between the CGIL and the CISL. This competition is partly explainable in purely union-related terms. The disappointing performance of the CISL candidates in what used to be regarded as CISL's turf, namely the public sector (see above), may have convinced the leadership of this organization that unity of action with the CGIL solely benefits the latter. In more general terms, the distance between CISL and CGIL on various issues has been growing for quite some time. CISL and CGIL have, in fact, quite different views on union democracy (with the CISL opposing, for example, widespread use of worker referenda), on decentralization of collective bargaining, and on flexibilization of wages and working conditions, the CISL being much more open than the CGIL on most of these issues.

\footnotetext{
7 This is due to the phenomenon known as "real wage resistance," i.e. the tendency of workers to compensate the erosion of their real wages, caused by exchange rate depreciation, with demands for greater nominal wage increases (see Carlin and Soskice, 1994: 294-300).
} 
These differences have recently led to "separate" agreements, i.e., agreements signed only by the CISL and the UIL but not the CGIL. ${ }^{8}$ The most serious of these incidents happened in 2001, when the CISL and UIL concluded without the CGIL a metalworking sector agreement with the Confindustria. Given the importance of the metalworking contract, this episode might come to be regarded in the future as a landmark in Italian industrial relations - much like the 1983 metalworking contract in Sweden, which is often singled out as marking the end of centralized bargaining in that country (see Pontusson and Swenson, 1996).

Partisan politics also played a role in re-opening the rift among the confederations. Before the 2001 general elections, which saw the return to power of a right-right coalition led by Silvio Berlusconi, the former secretary general of the CISL, Sergio D'Antoni, resigned from his leadership position within the confederation and established a new political party, Democrazia Europea, with the explicit goal of promoting the renaissance of the Christian Democratic Party (DC). The fact that one of the co-founders was Giulio Andreotti, long-time DC statesman, testified to the seriousness of the intent. The new party was unable to pass the four percent threshold needed for representation and it looks as though the CISL did not strongly support the leader's political ambitions. This failed initiative shows, however, that some people might seek to use the organizational strength of the CISL, with its four million members and potential voters, as springboard for the re-establishment of a centrist party, potentially alternative to both the left-left and the right-right electoral coalitions.

Only time will tell whether the present skirmishes will once again develop into fully-fledged warfare between the catholic and (post-)communist components of the Italian union movement. If so, the stability of the present system of social concertation is likely to be affected as well.

\section{The development of social partnership}

As argued in the preceding section, the re-emergence of social partnership in Italy took place in a climate of economic and political emergency. Discussions about the need to once again engage in centralized bargaining began in the early 1990s. In July 1992, the rapid deterioration of the country's macroeconomic situation forced the parties to sign a revolutionary agreement that abolished wage indexation and introduced a one-year moratorium on both firm-level wage negotiations and public sector collective bargaining.

Given the symbolic importance of particularly the wage indexation system (see Locke and Thelen, 1995), the Italian confederal unions came very close to replicating their 1984 split. Similar to events in 1984, the CISL, the UIL, and the Socialist faction within the CGIL were all favorable to the accord. The CGIL, however, opposed it. The government, in turn, announced that it would resign if the unions did not sign the deal. Unwilling to bear responsibility for political and economic instability, the secretary general of the CGIL, Bruno Trentin, signed the agreement but simultaneously offered his resignation (which he later withdrew).

The 1992 agreement met with both intra-union dissent (especially within the CGIL) and rankand-file demonstrations. Similar to 1984, the accord was not legitimated by a worker referendum. Also, the timing of the accord, signed on July 31, namely the day before the beginning of summer holidays in most industrial factories, was perceived as a trick designed to pre-empt rank-and file opposition. Workers in various industrial plants, particularly in the North of the country,

\footnotetext{
8 This happened, for example, with the proposed "Pact for Milan" in early 2000, which was signed only by CISL and UIL. This was a local-level concertation agreement aimed at allowing municipal authorities a more flexible use of fixedterm contracts in exchange for employment creation. See "Milano: firmato il patto della discordia." La Repubblica, Feb. $2,2000$.

9 The first part of this section relies on Baccaro, 2000 and forthcoming.
} 
participated in unofficial strikes against the agreement. Top union officials were violently confronted in various industrial cities.

In the midst of grass-root mobilization, CGIL, CISL, and UIL continued their negotiations with government and the Confindustria. In fact, they considered the 1992 agreement as a temporary, stopgap measure to be followed by a more extensive redesign of collective bargaining. In July 1993, a new agreement was reached. It confirmed the abolition of wage indexation, established tripartite consultations (in May and September) to link wage increases to the government's macroeconomic targets as stated in its yearly budget, and introduced a new architecture for collective bargaining based on two levels, the national and the peripheral - in the latter case, every four years. In fact, the agreement specified that on issues explicitly detailed in the national contract, bargaining could also take place at the company or territorial level. In this case, however, wage increases deriving from company-level bargaining were to be financed through productivity increases and/or performance improvements.

The establishment of two-level bargaining represented an important victory for the union movement, since the employers had pushed for a single locus of collective bargaining. The confederal unions hoped that this institutional innovation would increase the diffusion of collective bargaining at the peripheral levels. Their expectations do not seem to have materialized, however. The percentage of establishments engaging in collective bargaining declined from 23.7 percent in 1992 to 10.1 percent in 1994. In 1995 and 1996, this percentage increased to 12.2 and 22.1 percent, respectively. Despite this growth, the 1996 figure was still slightly below that of 1992 (Bordogna, 1997: Table 3, p. 75 and Bordogna, 1998: Table 7, p. 254). Other sources (Monitor, 1999) show that the proportion of workers covered by decentralized bargaining has stabilized ever since. According to these estimates, about two-thirds of workers in industry and private services are at present not covered by decentralized bargaining. This percentage is about the same as in the past.

The July 1993 accord was followed by a binding referendum among the workers - a first in the history of the Italian labor movement. About 1.5 million workers participated in the vote and of these, 68 percent approved the deal. The referendum proved to be a powerful legitimating device for the union confederal leadership. In fact, no grass-root uprising took place this time. Out of 50 sectors, only 3 (automotive, air transportation, and universities) rejected the agreement. However, the employees of some historic industrial plants voted (sometimes overwhelmingly) against the accord.

In 1995, social partnership was extended to the welfare state as well. The confederal unions negotiated with government a structural (long-run) reform of the Italian pension system. Early in the bargaining process, the Confindustria withdrew its bargaining delegation and later, refused to sign the agreement. This organization argued that the accord did not reduce (and in fact, slightly increased) social security contributions. In spite of the Confindustria's opposition, the 1995 reform was not without consequences. It introduced important long-term modifications. Pension benefits were not longer, as it had previously been the case, set as a function of past income but rather determined in accordance with accumulated social security contributions. This reform aimed at reducing pension expenditures and thus, reducing Italy's budget deficit as well. Similar to incomes policies, this new centralized agreement met with widespread internal opposition. Similar to incomes policies, however, dissent was ultimately diffused through the adoption of democratic procedures of legitimation.

After tentatively signing the accord, the unions organized a wave of workplace assemblies (approximately 42,000) to explain and discuss the agreement. The process of worker consultation was completed by a secret ballot referendum. Four and a half million people voted and 64 percent of them approved the reform. Pensioners voted overwhelmingly in favor of the accord ( 91 percent). This is hardly a surprise since the reform affected future retirees only. Active workers approved the reform as well, although with a lower percentage ( 58 percent) and a level of support that varied by sector and region. Once again, the largest area of dissent was in Northern industrial factories. 
Southern Italian workers appeared to be more supportive of pension reform than their Northern colleagues. On a national basis, the important categories of workers, the metalworkers and the school teachers, turned down the accord.

Similar to the incomes policy agreement, no major mobilization against the pension agreement took place. It is conceivable that this lack of mobilization was due to the organization of a binding referendum among all categories of workers. This clearly showed that the choice the engage in pension reform was not just an arbitrary imposition of union bureaucrats, as it had sometimes been argued in the past, but was actually supported by a clear majority of the Italian workers.

In 1996, social partnership moved to still another area of policy. The 1996 "Pact for Work" moderately increased labor market flexibility by introducing new forms of contingent work. The agreement also established that this kind of work was not admissible in workplaces where there had been layoffs in the past 12 months. Nor could it be used to replace workers on strike. Perhaps more importantly, only skilled employees (and not also un- or semi-skilled workers) could be employed through these contingent work contracts (Leonardi, 1998).

In 1997, the parties agreed to another pension reform. In fact, the 1995 pension reform would become fully effective only after a long transition period. In the meantime, generous "acquired rights" would be maintained. The 1997 pension reform sought to accelerate the transition to the new regime. However, due to the opposition of a crucial component of the governmental coalition, the Party of the Communist Refoundation (RC), the changes in eligibility rules could ultimately only be applied to white-collar workers.

In December 1998, the three confederal unions, government, and the Confindustria signed a socalled "Christmas Pact." This pact confirmed the structure of collective bargaining based on two levels. This structure had been established in 1993. It also confirmed and extended the practice of social concertation. It introduced an obligation for government to consult with the social partners on all social policy issues and, in some cases, even to devolve decision-making authority to the social partners so that they could directly regulated certain issues with no need for government involvement (Baccaro, 1999).

Besides widening in scope, social partnership also deepened over time and moved to the peripheral levels. In fact, one of the goals of the 1996 Pact for Work was encouraging territorial concertation through the regulation of essentially two instruments: the so-called "area contracts," aimed at dealing with economic/employment crises in particular areas, and the "territorial pacts," which brought together several local actors in partnerships aimed at promoting a favorable business environment in underdeveloped areas, especially in the South of the country.

This program of local concertation, supported by the European Union as well, sought to combine private and public intervention and differed considerably from previous top-down approaches to economic development in the South (Trigilia, 1992; Cersosimo, 2000; Bonomi and De Rita, 1998). Local actors were asked to form partnerships and present projects. The Treasury was then asked to evaluate the projects, select the most promising of them, and provide public funding to match moneys raised locally.

In the year 2000, 61 agreements had been approved and funded. They involved 1,417 municipalities and covered about 42 percent of the Southern population. These agreements were expected to increase employment by 27,000 units, 15,000 of which in the South. We still do not know how effective these pacts are in promoting economic growth and in making a dent in unemployment, which reaches 30 percent in certain Southern areas. Some of the local partnerships appear to have been solely finalized to gaining eligibility for public funding. Other partnerships, however, appear to have given rise to groupings that did not previously existed, strengthened relationships that were previously weak, and generated higher levels of trust among local economic actors (CNEL, 1999). It is perhaps worth emphasizing that these local pacts go well beyond the traditional tripartite structure and involve new actors like banks, universities, cooperatives, non-for- 
profit organizations, etc. In this way, they may be contributing to generate "social capital," which is increasingly regarded as an important prerequisite of development (Putnam, 1992).

If it is still too early to evaluate the economic impact of the territorial pacts, it is slightly easier to assess the contribution of national partnership. The composite of social pacts negotiated in the 1990s allowed the Italian economic authorities to engineer a massive devaluation of the Lira without appreciable increases in the inflation rate. It also helped them rally the necessary popular consensus for fiscal austerity measures needed to qualify for the second phase of EMU (Modigliani et al., 1996; Salvati, 2000). Social partnership also seems to have worked well for the confederal unions. They became key actors in all of Italy's economic policy decisions, not just industrial relations or collective bargaining. Also, there is no evidence that their heavy involvement in the political sphere had negative consequences in terms of membership. As argued above, much of the decline in membership happened in the 1980s (when collective bargaining was decentralized), not in the 1990s. Also, a large majority of workers continued to identify with these unions and did not defect to competitive organizations, as it was confirmed by various workplace elections in both the private and public sectors.

One of the interesting aspects of the Italian model of social partnership is the gulf existing between this model and traditional accounts of corporatism (Baccaro, 2001). The Italian industrial relations system had very few, if any at all, of the institutional preconditions once deemed necessary for this kind of deals to succeed. In particular, absent from the Italian scenario was a centralized and hierarchical structure of the labor movement. During the 1990s, the organizational structure of the Italian unions underwent important changes. None of these changes strengthened, however, the formal prerogatives of the peak organizational levels. On the contrary, they increased the rank-and-file's power to both elect their representatives and determine the movement's strategic orientation. Rather than weakening the confederal unions' capacity to engage in national policymaking, these reforms actually strengthened it.

\section{Organizational reforms}

In the late 1980s, the confederal unions' representational monopoly was threatened by a variety of alternative organizations. Their emergence had occurred in two phases (see Carrieri and Tatarelli, 1997). First, during the 1970s, a myriad of autonomous unions had appeared as a response to the egalitarian, class-based strategy of representation adopted at that time by the confederal unions. While the confederal unions targeted a particular category of workers, i.e., the operaio massa (semi-skilled assembly line worker), new professional unions endorsed the demands of white collar, technical, and professional workers in the air transportation, banking, insurance, health care, and school sectors. These new organizations proposed a less ideological and more "bread and butter" approach to labor issues and emphasized themes like the reopening of wage differentials and the negotiation of merit pay. A few years later, these unions adopted more stable organizational structures. In fact, during the 1980s, new confederations such as the CISAL and the CONFSAL were constituted by various autonomous unions in different sectors.

Second, during the latter half of the 1980s, the comitati di base or COBAS (i.e., grass-root committees) appeared in many of the same sectors in which the autonomous unions were already present (Bordogna, 1994). In many cases, the COBAS were established by previous members of the CGIL (Lombardi, 1989). The COBAS contested the three major union confederations from the left of the political spectrum. These unions objected to the strategy of appeasement and moderation that the confederations had embraced beginning with the late 1970s (Lange and Vannicelli, 1982; Golden, 1988; Locke, 1995: ch. 3) and sought to promote a return to worker opposition and mobilization. The COBAS were rooted in particular occupational communities, like the locomotive engineers and, at least initially, the schoolteachers. Therefore, their rekindling of class-based 
conflict was in practice limited to the defense of particular categories. The COBAS' basic demands were twofold. First, they demanded more money and better working conditions for their constituents. Second, they sought to promote greater democracy within the unions. Like other groups inside the confederal unions, and particularly within the CGIL, the COBAS believed, in fact, that the reason why the policy of wage moderation and quiescence had been able to take root in the Italian labor movement had to do with the transformation of the Italian union confederations from participatory into bureaucratic, hierarchical, and internally undemocratic organizations (see Baccaro, 2000). The COBAS were responsible for a wave of strikes that paralyzed the Italian public sector, particularly the school and transportation sectors, in the late 1980s (Bordogna, 1988).

As a result of these developments, the representativeness of Italy's three major confederations was called into question by many observers, both outside and inside the labor movement (Locke and Baccaro, 1996). The COBAS' demand for greater union democracy, as well as their hostility towards the policy of wage moderation, resonated in fact with similar positions of the more leftist factions within the CGIL. Also, the employers began to wonder aloud whether the three union confederations were really to be regarded as reliable bargaining partners. The size of the new organizations was unknown, but their capacity to mobilize the rank-and-file workers, and to mobilize them against the established unions, was often quite impressive.

In response to these internal and external attacks, the Italian confederal unions engaged in organizational reforms aimed at increasing internal democracy and transparency. Beginning with the 1987 metalworking contract, they submitted all major collective bargaining agreements, including the 1993 accord on incomes policy, the 1995 accord on pension reform, and the 1997 accord on pension reform (see above), to the binding approval of the rank-and-file (Battisti and Accornero, 1987). This was instrumental in re-legitimizing the confederal unions' role as bargaining agents in the eyes of both the employers and the rank-and-file workers. Also, they launched a series of organizational changes aimed at regularly electing workplace representatives.

These efforts culminated in the July 1993 protocol on incomes policies (see above). This protocol, in fact, included a thorough reform of the unions' plant-level representation structures. On the basis of this reform, the existing Rappresentanze Sindacali Aziendali, were to be replaced by unitary union structures, the so-called Rappresentanze Sindacali Unitarie (RSU). Unlike the past, elections for the new RSU could be contested by any organization capable of gaining the support of at least five percent of the workforce. However, only two-thirds of the representatives in these new firm-level structures were to be elected, whereas the remaining one-third was appointed directly by the confederal unions (Carrieri, 1995). As it has been shown above, the results of the elections largely confirmed the representativeness and legitimacy of the established confederal unions especially (but not exclusively) in the private sector. With the exception of clearly delimited occupational communities, the COBAS and other organizations turned out to be almost insignificant in the private sector. In 1997, the model of the RSU was extended to the public sector as well (see above), where it provided an opportunity for workers to elect their representatives (in most cases, for the first time) and for policy-makers to measure the representational capacity of the non-traditional unions. These elections showed that some of the protagonists of the late-1980 wave of public sector strikes, i.e., the COBAS, did not have a large base of support. Clearly, organizational strength and mobilization capacity did not necessarily go hand in hand.

Organizational reforms appear to have lost momentum in the last few months. In fact, the legal institutionalization of the RSU was never extended from the public to the private sector. A draft law, based on a compromise between CGIL, CISL, and UIL, has been under discussion throughout the past legislature. This law was never implemented. Opposition by the Confindustria (which opposed the extension of the RSU to small enterprises) contributed to stall the project. Renewed divisions among the confederal unions eventually torpedoed it. The new government has recently 
announced that it will not implement any law on union representativeness and union elections (Ministero del Lavoro, 2001).

The enthusiasm for organizational democracy seems to have petered out. The use of democratic decision-making procedures has the characteristic of providing clear-cut, unambiguous answers to questions like "whose policies are supported by the workers and whose are not." This clarity may come to be regarded as a liability in a phase of renewed organizational competition. Union organizations may choose to set these procedures aside and return to less threatening methods of inter-organizational negotiation and mediation. It is unclear, however, whether this choice really pays off in the long run.

\section{The strategies that worked}

This paper has argued that the Italian unions did relatively well in the 1990s. To be sure, this "success story" has to be qualified in light of the Italian unions' continuing loss of active workers, of the substitution process between active and retired members taking place within their ranks, and of their low capacity to organize new members in the occupationally most dynamic sectors of the economy (i.e., the private service sectors). Despite these developments, the confederal unions have been able to reverse the situation of impending economic and political marginalization of the 1980s and have been able to re-impose themselves as key actors in the Italian socio-political sphere. These are no negligible achievements, especially when regarded in comparative perspective.

As argued in the paper, not all of the Italian confederal unions' renaissance was of the unions' own making. In the early 1990s, a giant opportunity opened up for them in the political sphere. Relatively weak central governments faced with a major political economic crisis and in need of drastic economic policy reforms strongly expressed a "demand" for union participation in policymaking. The unions' ability was in seizing this opportunity and in responding accordingly. In other words, the unions were able to "supply" the concertation that was requested from them (see also Salvati, 2000). Consistent with this basic scheme, the Italian confederal unions adopted a strategy of cooperation with the other main socio-economic actors throughout the 1990s. Cooperation at the national level was soon extended to the peripheral levels as well as integrated with pre-existing (and relatively well-studied) experiences of cooperation at the local and workplace levels (see Bagnasco, 1977; Piore and Sabel, 1984; Trigilia, 1986; Regini and Sabel, 1989; Locke, 1995; Regini, 1995).

This strategy of cooperation implied that the Italian unions had to make tough choices. They had to consent to a period of prolonged wage moderation in which wages remained barely in line and sometimes even considerably below productivity increases. They also had to participate in unpopular policies like welfare state retrenchment and labor market flexibilization. In the end, these unions did not have a lot to show to their members in terms of material benefits. They could only argue, counterfactually, that things would have been worse - i.e., welfare cuts both deeper and more unequally distributed, labor market deregulation more extensive, and the workers' material conditions on average worse - had the unions not been there to make sure that basic guarantees for the weakest segments of the workforce were maintained, that "sacrifices" were equally distributed, and that cuts in workers' entitlements were accompanied by the elimination of the privileges enjoyed by other categories.

Interestingly enough, the Italian workers appeared to reward their confederal leaders rather than penalize them. In fact, the loss of active members first slowed down and then stopped altogether over the course of the 1990s. This is quite surprising if one considers that the Italian industrial relations system is extremely fragmented and that a multitude of labor organizations compete with the three major confederations for collective representation. Some of these organizations emphasize conflict rather than cooperation. Others base their representational strategy on the defense of particular worker groups. One would perhaps expect a strategy of restraint and 
moderation to impose a heavy toll on the confederal organizations and reward instead those who oppose it. Yet this does not seem to have happened. ${ }^{10}$

This strategy of cooperation was successful for multiple reasons. Unity of action played an important role. Unlike the past, all the three union confederations, CGIL, CISL, and UIL, singlehandedly supported this strategy. The fact that all political sponsors were part of the same governmental coalition probably helped. Particularly for the CGIL, however, adoption of this cooperative strategy was also the outcome of a long, sometimes contradictory, but largely selfdirected process of ideological revision. This organization radically transformed its perception of what a union is and what it should do, from agent of social dissent to partner in the process of economic change. An important landmark in this process was the 1991 National Congress, in which the CGIL dismissed the goal of class struggle, adopted bargaining demands that were compatible with the firms' long-term economic viability in a capitalist economy, and began pursuing "codetermination" rather than the radical transformation of the social relations of production (see Mershon, 1992, for more on this). Not all internal factions within the CGIL shared this new perspective. Some continued to believe in class struggle. The relationship between factions became, however, one of democratic competition - one in which whoever is able to gain the support of the majority of the workers wins and the other accepts the will of the majority.

Another important determinant of the unions' success in pursuing their cooperative strategy was the search for transparency and democracy. The received wisdom about corporatist deals like the ones the Italian confederal unions engaged in, e.g., incomes policies and pension reforms, is that these deals are most effective when they are struck in smoke-filled rooms by peak leaders largely unaccountable to their rank-and-file constituents. One of the basic tenets of neo-corporatist theory is that this very unaccountability is what makes the deals possible in the first place (see Baccaro, 2001, for an articulation of this argument). In fact, the neo-corporatist literature of the 1970s and 1980s implicitly assumed and sometimes explicitly argued that to ensure rank-and-file acquiescence to "austerity" policies, union leaders needed a series of institutional resources (e.g. compulsory membership, public or semi-public recognition and/or financing) that allowed them to impose on workers a series of outcomes these might not voluntarily subscribe to (see Offe, 1981, Panitch, 1979, and Pizzorno, 1978, for illustrations). This meant, among other things, that an "undemocratic" process of internal decision-making was required (Schmitter, 1979; Wolfe, 1985; Streeck, 1994).

Rather than following the prescriptions of neo-corporatist theory and insulating themselves from the workers' reactions, the Italian confederal unions took the opposite route. They sought to clearly explain why they embraced particular bargaining strategies and to make sure these policies were supported by the majority of their constituents. These choices implied both particular behaviors and appropriate organizational reforms. From the point of view of behaviors, union leaders preceded all major collective bargaining agreements, including the controversial 1993 incomes policy agreement and the 1995 and 1997 pension reforms, with thousands of workplace assemblies and binding referenda in which the contents of the proposed agreements were illustrated and the workers had an opportunity to express their views. The fact that a majority of them clearly expressed their support contributed to increase the legitimacy of the collective decisions adopted (see Lind and Tyler, 1988). From the point of view of organizational reforms, the confederal unions sought to revitalize their links with the rank-and-file by institutionalizing the regular electoral renewal of workplace representatives.

\footnotetext{
10 The recent experience of Ireland, another country where the union movement was involved in multi-year social partnership, also shows that partnership does not seem to negatively affect membership trends (see Roche and Ashmore, forthcoming).
} 
This last element leads us to consider one more determinant of success, the simultaneous pursuit of apparently contradictory strategies focused on both the "center" and the "periphery, "on both "political" and "grass-root" action. Traditionally, unions engaging in political exchange at the national level tend to overlook their local structures and invest fewer resources in their relationship with the rank-and-file (see Locke and Baccaro, forthcoming, for more on this). For example, centralized collective bargaining is often premised upon strict control over plant-level structures and sometimes even upon the hollowing out of decentralized collective bargaining. The recent Italian experience shows that the two strategies, of centralization and decentralization, are not only compatible with one another but are even mutually reinforcing. The confederal unions' strategy of revitalization of their workplace structures helped them mobilize the workers' support for national policies. At the same time, the political resources gained at the national level were used to introduce reforms (like the 1997 law mandating workplace elections and decentralized collective bargaining in the public sector) that further strengthened the peripheral levels.

This two-pronged strategy affected not only the unions' internal organization but also collective bargaining structures. The bargaining architecture introduced at the request of the unions by the 1993 tripartite agreement (confirmed in 1998 by another tripartite pact), sought to avoid the usual trade-offs between standardization on the one side, and local flexibility on the other. An interesting structure of "nested" collective bargaining combined the central negotiation of national guidelines with the possibility of adjustment at the local level. Thanks to this structure of collective bargaining, the unions were active at both the national and local levels, in a coordinated fashion. As such, they had fewer reasons to fear collective bargaining decentralization than in the past (Katz, 1993; Pontusson and Swenson, 1996; Thelen, 2000). This decentralization could actually turn out to be a strategic opportunity for them.

Having painted a rosy picture of the Italian unions' strategic capacities, we hasten to add, at this point, that not all strategic opportunities were grabbed in the 1990s. The golden opportunity missed was the merging of the three major confederations into a single organization. This would have finally realized one of the Hot Autumn's dreams. In 1996 and 1997, when the CGIL and the CISL held their conventions, unity appeared to be just behind the corner. Even a date, the year 2000, had been set for the symbolic event. Now union unity is once again a remote possibility. We regard this as perhaps the major threat for the future.

As mentioned above in the paper, particularly CGIL and CISL have different views on various topics and their differences have been growing in the past few months. Yet many of these differences are unlikely to matter much for rank-and-file workers. Also, the distance separating the median CGIL and CISL member on many of these issues is probably lower than the distance between two members within the CGIL, one affiliated with the "right" and the other with the "left" faction. We can think of no other reasons than organizational inertia and personal ambitions (on all sides) to explain why union unity did not become a reality in the 1990s.

The re-emergence of political competition among the three union confederations threatens to undo many of the gains these organizations have accumulated in the last decade. Most accomplishments have been only weakly institutionalized (Cella, 1989). They rest on the consensus of all parties involved. The legal status of concertation, for example, is that of a contract between government and various interest groups - a contract that can be renegotiated or worse, reneged upon by future governments. Also, the regular election of workplace representatives has become a law in the public sector but is still based on voluntaristic arrangements in the private sector.

It would be ironical if the Italian confederal unions were to unlearn the lessons of the 1980s and 1990s and squander whatever strategic advantage they have been able to accumulate in the last ten years. This might imply the return to an old phase of Italian industrial relations in which a portion of the labor movement signs "sweetheart" deals with governments and/or the employers while 
another portion plays the role of unconditional opposition. But stranger things have been known to happen in Italy and this eventuality can not be ruled out at this point in time. 


\section{References}

Armstrong, P., A. Glyn, and J. Harrison, 1991. Capitalism since 1945. Oxford. Blackwell.

Baccaro, L. forthcoming, "Negotiating the Italian Pension Reform with the Unions: Lessons for Corporatist Theory." Industrial and Labor Relations Review.

Baccaro, L. 2001, "The Construction of 'Democratic' Corporatism in Italy." Paper presented at the Max Planck Institute for Social Research, Cologne, Germany, March 23.

Baccaro, L. 2000, "Centralized Collective Bargaining and the Problem of 'Compliance': Lessons from the Italian Experience." Industrial and Labor Relations Review, 53(4): 579-601.

Baccaro, 1999, "Il sistema italiano di concertazione sociale: problemi aperti e prospettive di evoluzione." Unpublished ms., Case Western Reserve University, Cleveland, $\mathrm{OH}$.

Baglioni, G., ed. 1980, Analisi della CISL. Two volumes. Rome: Edizioni Lavoro.

Bagnasco, A. 1977, Le tre Italie. Bologna : Il Mulino.

Battisti, R. and A. Accornero, 1988, "I referendum sulle ipotesi di accordo dei contratti dell'industria." CESOS, Le relazioni sindacali in Italia. Rapporto 1986-87. Rome: Edizioni Lavoro.

Bonomi A. and G. De Rita, 1998, Manifesto per lo sviluppo locale, Torino, Bollati Boringhieri.

Bordogna, L. 1998, "La contrattazione decentrata nell'industria." In CESOS, Le relazioni sindacali in Italia. Rapporto 1996-97. Rome: Edizioni Lavoro.

Bordogna, L. 1997, "Un decennio di contrattazione aziendale nell'industria. Tendenze quantitative.” In L. Bellardi e L. Bordogna, eds., Relazioni industriali e contrattazione aziendale. Milan: Franco Angeli: 61-111.

Bordogna, L. 1994, Pluralismo senza mercato. Milan: Angeli.

Bordogna, L. 1988, "The COBAS: Fragmentation of Trade Union Representation and Conflict." In Robert Leonardi and Piergiorgio Corbetta, eds., Italian Politics: A Review. London: Pinter.

Carcano, M. 2000, "La rappresentanza." In CESOS, Le relazioni sindacali in Italia. Rapporto 1997- 98. Rome: Edizioni Lavoro.

Carlin, W. and D. W. Soskice, 1990, Macroeconomics and the Wage Bargain. Oxford: Oxford University Press.

Carrieri, M. 1995, L incerta rappresentanza. Bologna: Il Mulino.

Carrieri, M. and L. Tatarelli, 1997, Gli altri sindacati. Rome: Ediesse.

Cella, G.P. 1989, "Criteria of Regulation in Italian Industrial Relations: A Case of Weak Institutions.” In P. Lange and M. Regini, eds. State, Market, and Social Regulation: New Perspectives on Italy. New York: Cambridge University Press.

Cersosimo D., 2000, “I patti territoriali." In Cersosimo D. and Donzelli, MezzoGiorno. Rome, Donzelli.

CESOS, various years, Le relazioni sindacali in Italia. Rome: Edizioni Lavoro

CNEL, 1999 "Rapporto sulla concertazione locale." In Laboratori territoriali, Cnel: Rome.

Codara, L. 2000, "La sindacalizzazione." In CESOS, Le relazioni sindacali in Italia. Rapporto 1997-98. Rome: Edizioni Lavoro. 
Golden, M. 1988 Labor Divided. Austerity and Working-Class Politics in Contemporary Italy. Ithaca, NY: Cornell University Press.

ILO, 1998 World Labour Report, 1997-98. Geneva: ILO.

Katz, H. 1993, "The Decentralization of Collective Bargaining: A Literature Review and Comparative Analysis." Industrial and Labor Relations Review, 47(1): 3-22.

Lange, P. and M. Vannicelli, 1982, "Strategy Under Stress: The Italian Union Movement and the Italian Crisis in Developmental Perspective." In P. Lange, G. Ross, and M. Vannicelli, Unions, Change, and Crisis. Boston: George Allen and Unwin, 1982: 95-206.

Leonardi, S. 1998, "La contrattazione interconfederale." In CESOS, Le relazioni sindacali in Italia. Rapporto 19996- 97. Rome: Edizioni Lavoro: 153-70.

Lind, E.A. and T.R. Tyler, 1988, The Social Psychology of Procedural Justice. New York, NY: Plenum.

Locke R. 1992, "The Demise of the National Union in Italy: Lessons for Comparative Industrial Relations Theory." Industrial and Labor Relations Review, 45(2): 229-49.

Locke R. 1995, Remaking the Italian Economy. Ithaca, NY: Cornell University Press.

Locke, R. and L. Baccaro, forthcoming, "Pedagogy and Politics in the Italian Union Movement: A Tale of Administrative Failure." In R. Locke and K. Thelen, eds. Redrawing the Boundaries of Contemporary Labor Politics. Cambridge, MA: MIT University Press, forthcoming.

Locke, R. and L. Baccaro, 1999, "The Resurgence of the Italian Unions?" In A. Martin and G. Ross, The Brave New World of European Labor. New York: Berghahn Books, 1999: 217-68.

Locke, R. and L. Baccaro, 1996, "Learning from Past Mistakes? Recent Reforms in Italian Industrial Relations." Industrial Relations Journal, 27(4): 289-303.

Locke R. and K. Thelen, 1995, "Apples and Oranges Revisited: Contextualized Comparisons and the Study of Contemporary Labor Politics." Politics and Society, 23(3): 337-68.

Lombardi, E. 1989, Cobas: una spina nel fianco. Rome: Sovera Multimedia.

Mershon C. 1992, "The Crisis of the CGIL: Open Divisions in the Twelfth National Congress." In S. Hellman and Gianfranco Pasquino, eds. Italian Politics: A Review, Volume 7. New York: Pinter.

Ministero del Lavoro, 2001, "Libro bianco sul mercato del lavoro in Italia." Rome: Ministero del Lavoro, Oct.

Modigliani, F., M. Baldassari, and F. Castiglionesi, 1996, Il miracolo possibile. Bari: Laterza.

Monitor, 1998, "Concertazione, relazioni industriali e politica economica: il modello Offe, C. 1981, "The Attribution of Public Status to Interest Groups: Observations on the West German Case." In S. Berger, ed. Organizing Interest in Western Europe. New York: Cambridge University Press, 1981: 123-158.

Panitch, L. 1979, "The Development of Corporatism in Liberal Democracies." In P. Schmitter and G. Lehmbruch, eds. Trends Towards Corporatist Intermediation. London: Sage, 1979: 191-46.

Piore M. and C. Sabel, 1984, The Second Industrial Divide. New York. Basic Book italiano,"Rome: Ministero del Lavoro.

Mortillaro, F. 1984, Sindacati e no. Milan: Edizioni del Sole-24 Ore.

Mortillaro, F. 1986, Aspettando il robot. Milan: Edizioni del Sole-24 Ore.

Pizzorno, A. 1978, "Political Exchange and Collective Identity." In C. Crouch and A. Pizzorno, eds. The Resurgence of Class Conflict in Western Europe since 1968. Volume 2. London: Macmillan. 
Pontusson, J. and P. Swenson, 1996, "Labor Markets, Production Strategies, and Wage Bargaining Institutions: The Employer Offensive in Comparative Perspective." Comparative Political Studies, 29(2): 223-50.

Putnam, R. D. 1992, Making Democracy Work. Princeton, NJ: Princeton University Press.

Regini, M. 1995, Uncertain Boundaries. New York: Cambridge University Press.

Regini, M. and C. Sabel, 1989, Strategie di riaggiustamento industriale. Bologna: Il Mulino.

Roche W. K. and J. Ashmore, forthcoming, "Irish Unions in the 1990s: Testing the Limits of Social Partnerships." In G. Griffin, ed., Changing Patterns of Trade Unionism. Sidney: Criterion.

Salvati, M. 2000, "Breve storia della concertazione all'italiana." Stato e Mercato, 60, Dec.: 447-476.

Salvati, M. 1984, Economia e politica in Italia dal dopoguerra a oggi. Milan: Garzanti.

Schmitter, P. 1979, "Still the Century of Corporatism?" In P. Schmitter and G. Lehmbruch, eds. Trends Towards Corporatist Intermediation, London: Sage: 7-49. First published in Review of Politics, XXXVI, 1974: 85-131.

Streeck, W. 1994, "Einleitung des Herausgebers. Staat und Verbände: Neue Fragen. Neue Antworten?"Politische Vierteljahresschrift. Sonderheft, 25: 7-34.

Tarrow, S. 1994, Power in Movement. New York, Cambridge University Press.

Thelen, K. 2000, "Varieties of Labor Politics in the Developed Democracies." Unpublished ms., Northwestern University.

Trigilia, C. 1992, Sviluppo senza autonomia. Bologna : Il Mulino.

Trigilia, C. 1986, Grandi partiti e piccole imprese. Bologna : Il Mulino

Vaciago, G. 1993, "Exchange Rate Stability and Market Expectations: The Crisis of the EMS." Review of Economic Conditions in Italy, No. 1, January-April: 11-29.

Weitz, P. 1975, "Labor and Politics in a Divided Movement: The Italian Case." Industrial and Labor Relations Review, 28(2): 226-42.

Wolfe, J. 1985, "Corporatism and Union Democracy: The British Miners and Incomes Policies, 1973-74." Comparative Politics, 17(4), July: 421-436. 


\begin{tabular}{|l|c|c|c|c|c|}
\hline \multicolumn{7}{|c|}{1997} \\
\hline CGIL & CISL & UIL & Total & Union. rate \\
\hline Agriculture & 249,581 & 196,88 & 121,587 & 568,048 & $86.7 \%$ \\
\hline Industry & $1,091,614$ & 630,214 & 374,168 & $2,095,996$ & $40.4 \%$ \\
\hline Marketable Services & 488,506 & 406,203 & 266,221 & $1,160,930$ & $20.3 \%$ \\
\hline Non-Marketable Services & 457,776 & 543,127 & 316,373 & $1,317,276$ & $44.8 \%$ \\
\hline Total Wage-earners & $2,287,477$ & $1,776,424$ & $1,078,349$ & $5,142,250$ & $35.5 \%$ \\
\hline Total self-employed & 565 & 106,847 & 91,484 & 198,896 & \\
\hline Pensioners & $2,875,459$ & $1,909,832$ & 418,437 & $5,203,728$ & \\
\hline Non-employed & 36,123 & 63,231 & & 99,354 & \\
\hline Total & $5,199,624$ & $3,856,334$ & $1,588,270$ & $10,644,228$ & \\
\hline
\end{tabular}

\begin{tabular}{|l|c|c|c|c|c|}
\hline \multicolumn{7}{|c|}{1990} \\
\hline CGIL & CISL & UIL & Total & Union. rate \\
\hline Agriculture & 314,069 & 251,657 & 121,154 & 713,880 & $84.60 \%$ \\
\hline Industry & $1,336,881$ & 715,517 & 407,078 & $2,459,476$ & $41.70 \%$ \\
\hline Marketable Services & 531,130 & 461,099 & 270,807 & $1,263,036$ & $24.10 \%$ \\
\hline Non-Marketable Services & 515,722 & 595,529 & 324,748 & $1,435,999$ & $48.20 \%$ \\
\hline Total wage-earners & $2,724,802$ & $2,023,802$ & $1,123,787$ & $5,872,391$ & $39.30 \%$ \\
\hline Total self-employed & 14,898 & 168,175 & 93,895 & 276,968 & \\
\hline Pensioners & $2,353,891$ & $1,274,489$ & 268,076 & $3,896,456$ & \\
\hline Non-employed & 56,785 & 41,925 & & 98,710 & \\
\hline Total & $5,150,376$ & $3,508,391$ & $1,485,758$ & $10,144,525$ & \\
\hline
\end{tabular}

\section{Table continued...}




\begin{tabular}{|l|c|c|c|c|c|}
\hline \multicolumn{7}{|c|}{1981} \\
\hline CGIL & CISL & UIL & Total & Union. rate \\
\hline Agriculture & 519,028 & 485,229 & 166,310 & $1,170,567$ & $100.06 \%$ \\
\hline Industry & $1,757,954$ & 950,560 & 481,947 & $3,190,461$ & $48.82 \%$ \\
\hline Private Tertiary* & 569,865 & 357,674 & 227,722 & $1,155,261$ & $27.13 \%$ \\
\hline Public Tertiary* & 551,557 & 685,879 & 312,438 & $1,549,874$ & $51.42 \%$ \\
\hline Total wage-earners & $3,398,404$ & $2,479,342$ & $1,188,417$ & $7,066,163$ & $46.64 \%$ \\
\hline Total self-employed & n.a. & n.a. & n.a. & n.a. & \\
\hline Pensioners & $1,186,207$ & 509,471 & 168,873 & $1,864,551$ & \\
\hline Non-employed & n.a. & n.a. & n.a. & n.a. & \\
\hline Total & $4,584,611$ & $2,988,813$ & $1,357,290$ & $8,930,714$ & \\
\hline
\end{tabular}

* non necessarily comparable with later years; private tertiary includes transportation as well.

Source: 1981, Guido Romagnoli, "Sindacalizzazione e rappresentanza." In Cesos, Le relazioni sindacali in Italia. Rapporto 1981. Rome : Edizioni Lavoro; 1982, p. 177; 1990: Corrado Squarzon, "La sindacalizzazione." In Cesos, Le relazioni sindacali in Italia. Rapporto 1990-91. Rome : Edizioni Lavoro, 1992 : 87; 1997: Lino Codara, "La sindacalizzazione." In CESOS, Le relazioni sindacali in Italia._Rapporto 1997-98. Rome: Edizioni Lavoro, 2000. 